\title{
Profesor BORUT BELEC, osemdesetletnik
}

Ob jubilantovi sedemdesetletnici sta v Geografskem vestniku $(73,1 ; 2001)$ avtorja poročila upravičeno zapisala, da je s svojim pedagoškim, znanstvenoraziskovalnim in organizacijskim delom nedvomno vodilni mariborski geograf in eden najvidnejših slovenskih geografov, ki je v svojem znanstvenem delu že zgodaj presegel regionalne okvire in se uspešno vključil v mednarodna geografska dogajanja. Ne le svoje delo, ampak tudi njemu najljubšo regijo med Dravo in Muro, še posebej pa Slovenske gorice z vsemi geografskimi in še posebej socialnogeografskimi procesi in problematiko, je približal mednarodnim geografskim krogom. In ker je bilo

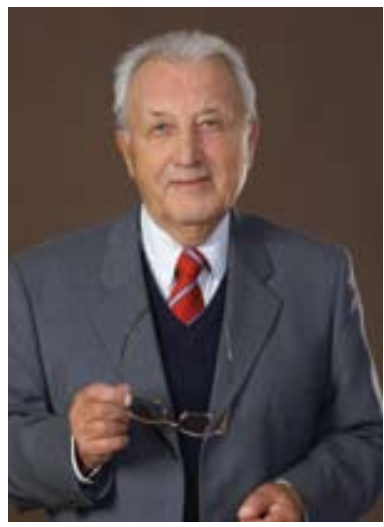
njegovo bogato strokovno, pedagoško in organizacijsko delo javnosti podrobneje predstavljeno že ob njegovi sedemedesetletnici v Geografskem vestniku in v drugih glasilih, vsega na tem mestu ne bi ponavljali.

Med slovenskimi geografi prof. Belec izstopa vsaj po dveh značilnostih. Pri svojem nadvse plodnem strokovnem, pa tudi pedagoškem delu je posegel na različna geografska področja, kar je bilo nedvomno povezano z njegovim več kot petdesetletnim intenzivnim sodelovanjem z osrednjimi slovenskimi geografskimi inštitucijami, Oddelkom za geografijo Filozofske fakultete, tri desetletja $\mathrm{z}$ Inštitutom za geografijo Univerze v Ljubljani in na začetku svoje strokovne poti $\mathrm{z}$ akademskim geografskim inštitutom. Ob pogostih srečanjih v Ljubljani niti pomislili nismo, koliko časa je žrtvoval za potovanja na seje, strokovna srečanja, na zagovore doktoratov, magisterijev in številnih drugih obveznosti, ki jih ni nikoli odklanjal. Izredno priljubljenost si je pridobil s svojo prijaznostjo, delavnostjo, strokovno korektnostjo in zanesljivostjo. Mirno ga lahko označimo za vodilnega zunanjega sodelavca Oddelka za geografijo. Tudi vsi slovenski študenti geografije že skoraj pol stoletja uporabljajo njegova večkrat dopolnjena skripta iz fizične geografije. Ob tem ogromnem opusu pa kolega Belec vendarle ni izpolnil dolgoletnega vabila, da bi svoje bogato znanje posredoval kdaj tudi ljubljanskim študentom geografije.

Jubilanta je znanstveno delo pritegnilo že v času študija in ga je po diplomi nadaljeval v sodelovanju z Geografskim inštitutom SAZU, predvsem na področju geomorfologije in regionalne geografije. Po ustanovitvi Pedagoške akademije v Mariboru leta 1961, na kateri je bil prvi profesor geografije, pa se je vključil v raziskovalne projekte Inštituta za geografijo Univerze v Ljubljani, ki je pod vodstvom ter mentorstvom prof. Vladimirja Klemenčiča in mentorstvom prof. Svetozarja Ilešiča pritegnil širok krog, predvsem za novo socialnogeografsko smer vnetih slovenskih geografov. Kljub svoji strokovni širini je prof. Belec tudi po ukinitvi Inštituta za geografijo svoje strokovno delo povezoval s socialnogeografsko usmerjenimi kolegi na Oddelku za geografijo FF v Ljubljani in v tem duhu je vodil tudi vrsto raziskovalnih projektov mariborskega oddelka, takrat že Pedagoške fakultete Severovzhodna Slovenija se ima prav temu sodelovanju zahvaliti za številne tehtne geografske študije, za izjemno dobro raziskanost posameznih procesov, območij in regije na sploh in za 
njeno razpoznavnost ne le v slovenski geografiji in v slovenskem prostoru, temveč tudi v mednarodni geografski literaturi. Prof. Belec, ki so ga sicer še vedno zanimala tudi različna druga vprašanja prostorske zgradbe in razvoja, se je še posebej poglabljal v agrarnogeografsko problematiko, podeželja na sploh in tudi v širša socialnogeografska vprašanja. Njegova številna predavanja o najbolj aktualni agrarnogeografski problematiki na slovenskih, državnih in mednarodnih znanstvenih sestankih doma in v tujini so zaradi posebnosti aktualne prostorske problematike, originalne metodologije in skrbne pripravljenosti vselej vzbudila veliko pozornosti. Bil je nepogrešljiv predavatelj na številnih medinštitutskih znanstvenih srečanjih ljubljanske Katedre za družbeno geografijo z geografskimi inštituti univerz v Frankfurtu, Bayreuthu, Varšavi, Pécsu, Heidelbergu, Münchnu, Amsterdamu in še kje. In čeprav je jubilant za svojo bogato znanstvenoraziskovalno delo prejel vrsto priznanj in med drugimi tudi nagrado Sklada Borisa Kidriča (sedaj Zoisova nagrada) za raziskavo vinogradništva, sadjarstva in hmeljarstva v Sloveniji, ga je prav njegova disertacija LjutomerskoOrmoške gorice (1967), ki jo je pripravljal v sodelovanju z inštitutsko in oddelčno socialnogeografsko raziskovalno skupino, promovirala tudi $\mathrm{v}$ mednarodnih geografskih krogih. Znanstvenoraziskovalna prizadevanja si je prof. Belec prizadeval poglobiti z organizacijo strokovnih srečanj in strokovnih stikov. Po njegovi zaslugi se je ob pomoči prof. Vladimirja Bračiča, prof. Božidarja Kerta in prof. Ludvika Olasa težišče slovenskih, pa tudi mednarodnih socialnogeografskih dogajanj takrat prestavilo kar v Maribor. Koliko mednarodnih stro-kovnih srečanj in drugih aktivnosti je v Mariboru in v regiji organiziral prof. Belec in tukaj sta se v šestdesetih letih neposredno srečali poljska agrarnogeografska in münchenska soocialnogeografska šola pod vodstvom svetovno znanih avtoritet prof. W. Hartkeja in prof. J. Kostrowickega.

Ob tako zagnanem znanstvenoraziskovalnem delu pa je jubilant opravljal še obsežno pedagoško delo, saj je na Pedagoški akademiji, kasneje fakulteti, predaval vrsto fizično-, družbeno- in regionalnogeografskih predmetov, pa še geografijo turizma, prometa in ekonomsko geografijo na Visoki ekonomsko-komercialni šoli v Mariboru.

Strokovna problematika je še danes v ospredju jubilantovega zanimanja in pogovorov s kolegi, še vedno pa je domačemu in ljubljanskemu oddelku pripravljen priskočiti na pomoč s strokovnimi poročili in nasveti. Slovenska geografija mu je hvaležna za prispevek k razvoju stroke, širša regija pa za nadpovprečen prispevek k njeni geografski prepoznavnosti. Slovenski geografi, še posebej pa vsi, ki z njim že dolgo sodelujemo in prijateljujemo, mu želimo zdravja in še dolgo njemu lastno živahnost ter uživanje v ožjem in širšem okolju prelepe Subpanonije.

\section{Mirko Pak}

